\title{
Growing Up in Post-Conflict Kosovo; Youth's Insecurities and Their Attitudes Towards Police
}

\author{
Fabienne L. R. Coenders \\ Ruhr-University Bochum, Bochum, Germany \\ Corresponding author: fabienne.coenders@rub.de; Tel.: +49 176631615 59; Fax: +49 2343214328
}

Submitted: 3 March 2020 | In revised form: 6 June 2020 | Accepted: 7 October 2020 |

Published: 9 December 2020

\begin{abstract}
This study aims to identify insecurities among youth in Kosovo, utilizing insights from the field to advance and deepen the concept of human security, capturing the connection between insecurity and affiliated agency. It also explores attitudes towards police in Kosovo, analysing youth perspectives on performance, procedural justice and distributive justice. Primary data from semi-structured focus group discussions with Kosovar youth are used for the analyses. Four main insecurities were identified: (1) job-related, (2) drug-related, (3) school-related, (4) physical insecurities. Ethnic tensions were a recurrent crosscutting theme. Attitudes towards police are generally perceived as poor and seem to stem mainly from a performance and procedural justice perspective. Recommendations for future research and policy conclude the article.
\end{abstract}

Keywords: attitudes towards police; human security; identity; Kosovo; post-conflict; youth

\section{Introduction}

In February 2008, Kosovo unilaterally declared its independence from Serbia after the Socialist Federal Republic of Yugoslavia had collapsed in 1992 and the State Union of Serbia and Montenegro split after a referendum in 2006. The declaration came "after years of strained relations between its Serb and mainly Albanian inhabitants. It has been recognised by the United States and major European Union countries, but Serbia, backed by its powerful ally Russia, refuses to do so, as do most ethnic Serbs inside Kosovo" [1]. Kosovo has a mixed past, with periods of confrontation as well as periods of contact and co-operation across ethnic and religious boundaries [2]. In the 1990s, however, the ethnical tensions reached a violent peak, which included ethnical cleansing and other war crimes from both sides, in the Kosovo War of 1998-1999. Kosovo is now home to about 2 million citizens, scattered over an area about one-fourth the size of the Netherlands $(10,887$ square kilometres).

Still, "in 2011, Kosovo received 19 times more developmental aid than the average developing country. Moreover, in per capita terms Kosovo received 50 times more peacekeeping troops and 25 times more funds from the international community than Afghanistan did after 2001" ([3], pp. 20-21). Although this assistance worked out differently in each country ([4], p. 36), "it has arguably contributed to the consolidation of hybrid state institutions, the reproduction of patron-client political relations, and the intensification and monetization of political marketplaces." It also clearly shows the involvement of the international community even more than ten years after the formal conflict ended. There are various reasons for this international interest. For the EU, it is in part related to its proximity to other EU member states: "The 
partnership between the EU and the Western Balkans is in the interest of all sides, promoting peace, stability, freedom, security and justice, prosperity and quality of life" [5]. The extent in which international assistance reached the local level and supported local ownership is criticized, especially for the UN mission in Kosovo (UNMIK) [3,4,6].

Despite the disproportionate amounts of international aid flowing into Kosovo, little seems to have changed [7]: macro-level issues such as corruption, nepotism and ethnic tensions between the Albanian and Serb populations in Kosovo still infest the region [8-10]. The developmental lags in Kosovo despite the large amounts of aid are particularly poignant, as the international community itself has essentially been sitting in drivers' seat when it comes to, for example, the Kosovar police reform and law-enforcement reform for the most part $[4,6,7]$.

This study takes a micro-level perspective to analyse the effects of these macro-level issues on the human security of Kosovo's youth in particular. By utilizing insights from the field and capturing the connection between insecurity and affiliated agency, the concept of human security is advanced and deepened. This group is not only of particular interest because it represents the future of Kosovo, it is also the largest age group within its society: about half the population is under the age of 25 , while approximately $65 \%$ is under 30 years of age [11]. Kosovo is not only Europe's youngest state; it also inhabits its youngest population.

The present study strives to give Kosovar youth a voice something that is not usually done according to some interviewees, despite the attempts made by e.g. youth councils, governmental youth action strategies, international actors, and so on - and is divided into two main parts, guided by two research questions per part listed below. The first part addresses insecurities for young Kosovars and the ways in which they (try to) resolve these issues. In many cases, the identified insecurities and respective resolutions are related to the role of and attitudes towards police (ATP) in Kosovo, which are addressed in the second part of this study. Building on the study design for ATP of Dirikx, Gelders \& Parmentier [12], both the perceptions and importance of the following three aspects of police work are addressed: (1) performance, (2) procedural justice and (3) distributive justice.

Part I

1. What insecurities do young Kosovars have growing up in post-conflict Kosovo?

2. What resolution mechanisms do young Kosovars emPart II ploy to overcome these insecurities, if at all?

1. What perceptions do Kosovar youth have of the performance, the procedural justice and the distributive justice of the police in Kosovo?

2. How much importance do Kosovar youth attach to the performance, procedural justice and distributive justice of the police in Kosovo?

Primary data from semi-structured focus group discussions with Kosovar youth are used. These focus groups are mainly explorative in nature for Part I: they aim to distil the insecurities of young Kosovars and then builds towards the second theme, based on the initial input from participants. The themes handled in Part II, on the other hand, are theoretically embedded in the frameworks described below.

\section{Defining (In)security}

"Security is an essentially contested concept." ([13], p. 74). Depending on the field of interest and the different schools of thought within a particular field, different definitions of security and its antonym are used. Generally speaking - that is, as defined by dictionaries - security is seen as something along the lines of 'being free from risk or danger'. This definition is similar to the notion of human security, often used in social sciences and referred to in this study when addressing (in)security for Kosovar youth. However, the definition of human security, too, is heavily contested in policy and academic debates. The term human security gained attention in the 1990s, where the UNDP examined human security as a dual agenda of "freedom from fear and freedom from want." Later, the Commission on Human Security defined human security as follows [14]: "Human security means protecting fundamental freedoms [...]. It means protecting people from critical (severe) and pervasive (widespread) threats and situations. [...] It means creating political, social, environmental, economic, military and cultural systems that together give people the building blocks of survival, livelihood and dignity."

Two opposing views have developed in the academic debate: a narrow and a broad understanding of human security. Those in favour of narrowing the concept emphasise the freedom-from-fear aspect, focussing on ([13], p. 76) "violent threats to individuals, while recognizing that these are strongly associated with poverty, lack of state capacity and various forms of socioeconomic and political inequity." Advocates of a broader concept of human security, instead, emphasise on keeping a more holistic approach. They argue that [15] "once the referent of the security agenda becomes the individual, it is impossible to disentangle violent threats to individuals from other issues such as poverty, environmental degradation, and infectious diseases that directly impinge on the safety, freedom, and self-realization of human beings." Either way, the term signifies an alteration in security studies, which traditionally focused on security of the state mainly [15]. Recent research has opted to utilize insights from the field to advance and deepen the concept of human security [16], capturing the (sometimes paradoxical) connection between insecurity and affiliated agency. This way, research can "[open] up processes of knowledge production that allow individual accounts to be constructed, acknowledged and validated has resulted in a collaborative understanding of human security"([16], p. 581) . According to the study by Kostovicova, Martin \& Bojicic-Dzelilovic, Kosovars mainly resort to self-reliance, informality and community solidarity to overcome their insecurities, but cannot relieve macro-level insecurities posed by a weak state. The results of this study (see 5.1) show similar resolutions (i.e. 
agency) applied by youth. This study addresses the agency of (young) individuals in Kosovo by investigating resolution mechanisms they employ to overcome everyday-life insecurities. Moreover, the exploratory nature of the research with youth posed here, suits the holistic and individualoriented understanding of security that the broad conception of human security offers. The focus group participants fully embraced a holistic approach of security, discussing both socioeconomic and physical insecurities, as well as the interconnections between them.

\section{Theoretical Framework on Attitudes towards Police}

In part II of this article, ATP of youth are addressed. In the literature, a variety of terms is used interchangeably with 'attitudes towards police' [12], and is often treated as a unidimensional concept measuring a general opinion about the police, also referred to as general support for - or confidence in the police (for example, [17-19]). When ATP is studied as a multidimensional concept, however, there are three main perspectives on ATP to be distinguished [12]: (1) the performance-based perspective, (2) the distributive justice perspective and (3) the procedural justice perspective. The performance-based perspective seems most straightforward: it argues that "people's ATP are mainly determined by their views on how effectively the police control crime. If people feel that the police are effectively controlling crime, that they are keeping the neighbourhood safe and that crime rates are low, their ATP can be expected to be positive." ([12], p. 193).

The distributive justice perspective emphasizes the importance of a fair distribution of police services across people and communities, regardless of their social, cultural, economic, ethnical or religious background, nor age or gender $[12,20]$.

Finally, the procedural justice perspective argues that ATP mainly revolve around the fairness in the decisionmaking process and way in which authority is exercised in general [21]. This final perspective can be divided into four underlying elements affiliated with positive procedural justice: (1) opportunities for participation, (2) friendliness and politeness, (3) neutrality and (4) trustworthiness [12,20]. This framework will be used for the analyses of the results (ad-hoc). It was not used to guide the of focus group discussions in any way.

\section{Material and Methods}

In the summer of 2018, nine semi-structured dualmoderator focus group discussions were conducted [22]. Participants from four out of seven main districts of Kosovo - Pristina, Prizren, Mitrovica and Ferizaj - were sampled through convenience and snowball sampling [23], targeting youth between 16 and 30 years of age who have not entered the labour market fully or formally yet [24]. The Serbian population in Kosovo is difficult to reach, as many boycott surveys and studies. For this study, fortunately, one focus group was conducted with Serbian youth too. In total, 46 participants took part in the focus group discussions. All focus groups were planned with at least seven participants each; however, some participants did not show up for their focus group. This thus sometimes resulted in smaller group sizes, but did not render the discussions any less informative or vibrant (sometimes, quite the opposite). The semi-structured focus group discussions covered the following main themes in line with the research questions set for this study: (1) insecurities for young Kosovars, (2) resolution mechanisms and (3) ATP.

It is crucial to conduct focus group discussions in the participants' native language so discussions can elapse fluently, especially when interviewing youth. Therefore, young Albanian-speaking Kosovars, who were trained by the researcher, conducted the interviews in Albanian. A Bosnian interviewer who speaks Serbian conducted the focus group with Serbian youth in order to retain a peaceful discussion. The researcher was present during all focus groups to observe the discussion process. The fact that these interviewers have a background in Kosovo and are young themselves provided them with an in-depth and sincere understanding of the participants. It also benefitted the atmosphere in which participants were able to speak openly. The fact that participants, especially in the beginning of the discussion, sometimes added sentences like "you know that already" to the interviewer, shows that they are aware of their background. In prospect, the interviewers were trained to emphasize the importance of speaking openly throughout the discussion, also if they thought the interviewer would know about it already. Both the observing researcher and the interviewers stressed this as well at the beginning of each focus group. This approach also helped to "collapse the distance between the outsider/researcher and those on the sharp end of insecurity, engaged as partners in the co-construction of the knowledge of security," as done in the study by Kostovicova et al. ([16], p. 581), be it in a different way.

An interview guide was set up to provide a broad frame to guide the discussions around these main themes, making sure none was left out. The guide was only created to keep the discussions on topic and to initiate discussions; not to systematically steer them by any theoretical background. This is also true for the theme on ATP, which is theoretically embedded into the framework presented above. Here, discussions were initiated by addressing participants' relation with police in general and by relating to the role of police in the previously identified insecurities in each focus group.

\section{Results}

\subsection{Part I: Insecurities and Resolutions}

Four main insecurities were identified in the conducted focus groups: (1) job-related (including job-related discrimination), (2) drug-related, (3) school-related, (4) physical insecurities. Ethnic tensions were a recurrent crosscutting 
theme, related to most of the aforementioned insecurities and addressed at the end.

\subsubsection{Job-related insecurities}

Kosovo is a so-called transition economy, moving from a centrally planned economy under Yugoslavian rule into a market-based economy [25]. The main sectors in the Kosovar economy include mining, energy, construction, agriculture and the textile industry [26]. In 2019, more than half of those who are employed work in trade, construction, manufacturing and education, according to data from the Kosovo Agency of Statistics [27].

In eight out of nine focus groups, the discussion started with concerns about getting a job and the high level of unemployment (see Figure 1) in combination with the poor economic situation (see Figure 2). It signifies the harsh conditions in the Kosovar work-sphere and youth are concerned about it even while still in school or college. Their concerns are not without good reason: the most recent statistics show that the overall unemployment rate hovers around $25 \%[27,28]$. Although unemployment rates have been higher in recent years, Kosovo still has the highest unemployment rate in the European area [29,30]. The rates for youth are even higher: approximately $55 \%$ of those aged between 15 and 24 were unemployed in 2018 [31] the year in which the interviews took place. Kosovo ranked third in (reported) youth unemployment around the world in 2019 - just behind South Africa and Libya [27,32]. More- over, the situation is getting worse [33]: "Every year, more than 30,000 young people enter the job market. Fewer than 8,000 find work." Youth often face two key disadvantages: lack of experience and a lack of a professional network $[34,35]$. Although the Kosovar government has made combatting youth unemployment a policy priority, sustainable progress is still to be made [35].

The current COVID19 pandemic and its aftermath will most likely worsen the situation. The impact of the pandemic on the labour market is expected to show in the Kosovo labour force data in the second quarter of 2020 , according to the Kosovo Agency of Statistics. "In Q1 2020 some businesses did not close their activities (Pandemic start) and the impact on the first quarter was very low [28] ."

A wave of job-losses also emerged during the war and its aftermath. For example, Kosovo lost most of its largest export facility: Trepca mine in the North, housing mainly lead, zinc, silver and a variety of minerals. Only a fraction of the mines is currently up and running, employing less than 1400 miners as opposed to some 23 thousand during its pre-war peak. The mining complex once accounted for over two-thirds of Kosovo's gross domestic product, but the strong ethnical tension between Kosovar Albanians and Serbs loyal to Belgrade in Mitrovica - as well as the costly need for repairs [33]- withholds most of Trepca's facilities from re-opening [36]. The young Kosovars in the North see this as a great loss of jobs, associated with the privatization of the mines and other previously state-owned factories throughout the country.

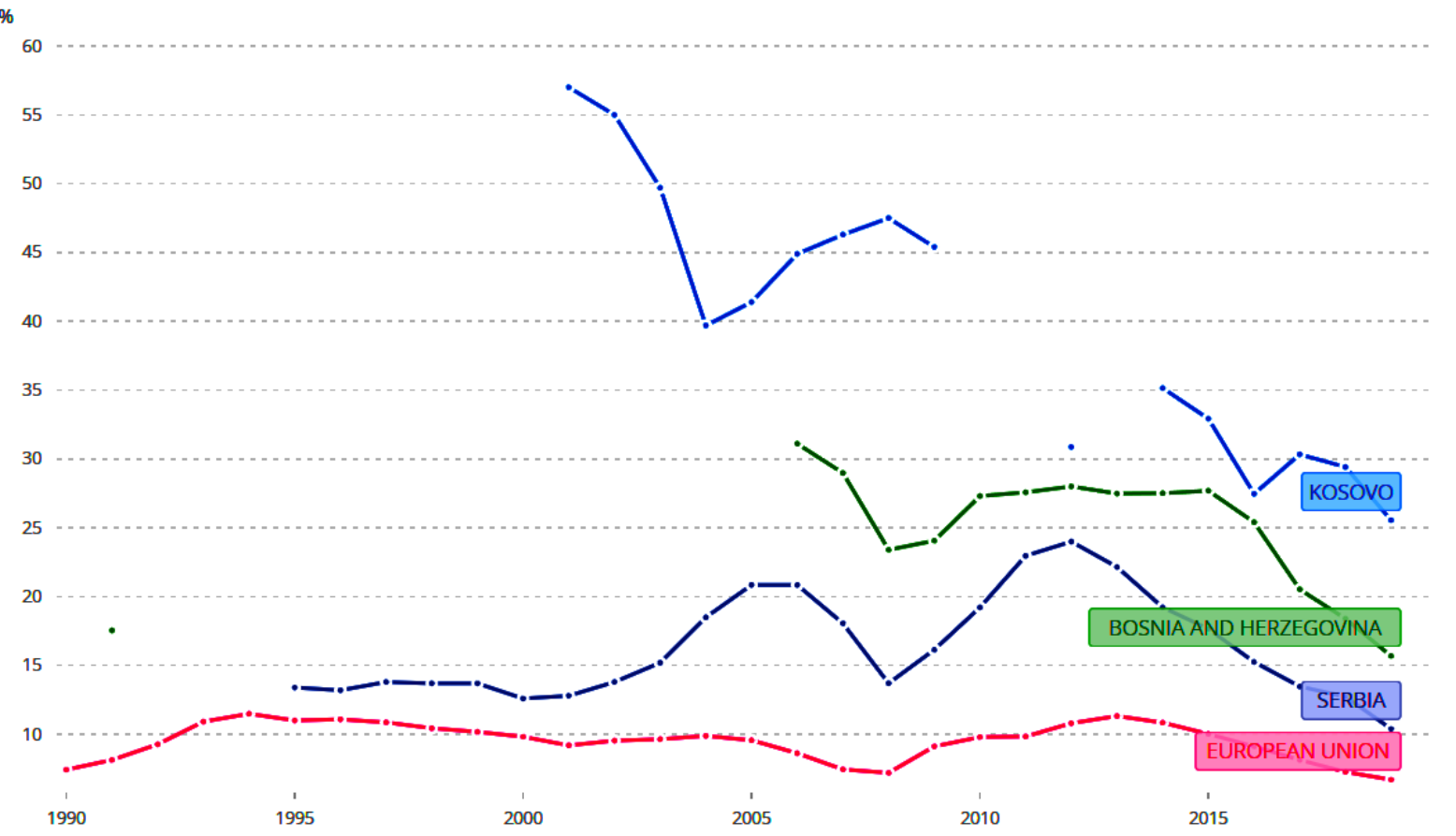

Figure 1. Unemployment trends as percentage of total labour force [29]. 


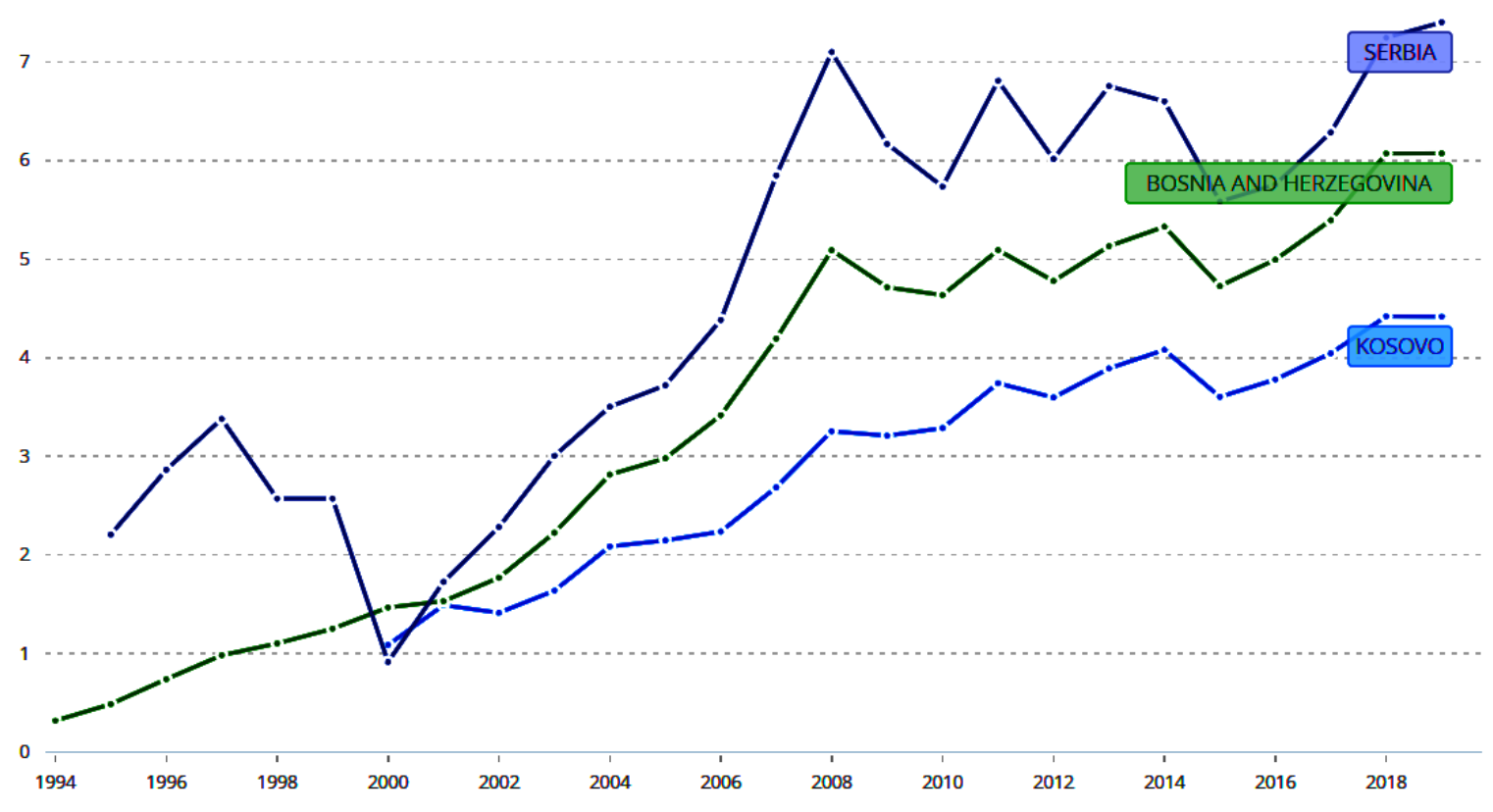

Figure 2. GDP per capita in thousands (current US\$) [37].

This study identified three main types of job-related insecurities for youth: (1) being hired for the wrong reasons, (2) the difficulty of getting a job in general and (3) the difficulty of getting a job on a higher level (suiting one's study field and level).

First of all, being hired for the wrong reasons seems to be a somewhat less common (or at least less discussed) insecurity; partly because getting a job is difficult in the first place and most participants were not yet employed. Nonetheless, it marks a poignant insecurity: "I've had it personally, I went to job interviews and that look that you get from head to toe is simply terrifying." The girl from Pristina, who described her experiences with such inappropriate and unprofessional job interviews, sees this form of harassment as a part of an ever-present fear for women in particular. More gender-based insecurities are discussed later (see 5.1.5).

The difficulties surrounding getting a job, let alone on a higher level, are present for almost all of the participants and are strongly related to the enduring poor job-market $[27,31]$ and youth disadvantages in experience and professional networks $[34,35]$. The mechanisms that seem to lie beyond are a variety of power relations deeply rooted in the Kosovar society. Having family or friends in the respective company or in high positions in general is necessary to get a job (nepotism), according to several young Kosovars. Another controversial way to get a job in Kosovo is by paying for it (corruption). Either way, doing neither strongly decreases your chances of getting the job, even if you are (more) skilled than other job applicants are.

Youth also report cases where "someone was not ac- cepted [for a job] unless they sent in a picture" or not being selected for a job because someone looks better. A girl from Mitrovica, currently working in a call centre as a side job, sums it up quite concisely: "We have to pay [to get a job]. We go with our CV but ... maybe there is someone more beautiful than we are; then she got the [job]! Or she has family there; she got the [job] too. So if we are just [...] going with a CV [to look] for a job, we are not going to get it."

Sadly, the youth is largely unable to employ effective resolutions for these job-related issues other than playing along (i.e. paying up) and hoping for the best (i.e. being lucky with family and/or friends in important positions). Attempts of utilizing the help of job-centres or using word of mouth (to improve professional network) and taking internships (to improve professional experience) to find job openings do not often seem to get significant results. In some cases, it was argued that it can help to look for jobs in branches or cities (read: Pristina, the capital) with more job openings, but it cannot overcome the general lack of job opportunities in Kosovo. To address these macro-level problematics, structural changes in society need to take place. Many young Kosovars see emigration into EU states as the resolution for job-related and financial insecurities. This emphasis on "getting out" showed from the mass emigration movement which took place in 2015. "Since we were kids, [...] you could hear grown-ups talking: 'There is nothing here, you have to leave.' There is this idea integrated that we have to leave in order to be successful," a girl from Pristina stated. 


\subsubsection{Job-related Discrimination}

Some job-related insecurities are more prominent for specific sub-groups of the population. "In a place [like Kosovo] with high unemployment and poverty rates, with a lack of an adequate social welfare system, as well as a low GDP, it becomes difficult to define marginalization and to map certain groups as marginalized. What is more, marginalized groups [in Kosovo] were not a subject of many studies, and even when they were, not all groups were covered." ([38], p. 103). Focus group participants identified two main characteristics prone to hiring discrimination (apart from youth' lack of experience and professional network, addressed previously): (1) political preference and (2) gender. Some focus groups, notably those held in Prishtina and Prizren, were particularly dominated by a discussion about political freedom in Kosovo. Some youth who participated there, were actively involved in discussion groups and voluntary work in their community and spoke about their experience as supporters of oppositional parties. A girl from Prizren describes political-based inequality as follows: "For example, someone is a part of a political party and is in opposition, they will be automatically excluded from the workplace [...]." This is an indication of the poor environment for critical reflection in the Kosovar political spectrum and sometimes results in physical threats (see 5.1.5). Kosovo passed progressive anti-discrimination laws in 2004 already $[39,40]$ but a need for better law enforcement remains when it comes to political discrimination as well as other forms of discrimination in the employment sector. While hiring discrimination based on ethnicity, age and gender has been explored at least to some extent in Kosovo (for example, [34,38,41]), research exploring political discrimination remains elusive.

For women, it can be more difficult to get a job, as "a man will get a job before the girl", a boy from a village near Mitrovica stated. The way in which he - probably unconsciously - worded his statement, shows exactly how deeply gender-inequalities are embedded into society (i.e. using 'man' and 'girl' as opposites, instead of 'man' and 'woman', or 'boy' and 'girl'). A female participant elaborated by arguing: "People think that the female gender is more sensitive and they take things too hard, so they can't take the right decision [...]." Gender stereotypes like these may put women in positions that are less paid or valued [38,41]. The Kosovar government thus imposed a 'special' status for women under the Law on Labour in article 44 to improve the protection of women employees and decrease hiring discrimination. However, "the same Law has negative effects on women as it predicts maternity leave at $70 \%$ of the average salary in Kosovo for the first six months, paid by the employer, and $50 \%$ of the average salary in Kosovo for the remaining three months, paid by the government" ([38], p. 104).

Whatever reasons employers may have for preferring men to women in the work force, it limits women and girls from being employed and thus gaining financial independence. On the up side, a participant from Pristina stated that an awareness raising campaign on sexist language is set up that seems to have positive effects. Change is slow in Kosovo and, sometimes, such small steps are the way to go.

\subsubsection{Drug-related insecurities}

Insecurities surrounding addictive substances are divided into two aspects: (ab)use and dealing. It is difficult to gain comprehensive insight in the extent of drug (ab)use in Kosovo. Although many organisations in Kosovo collect information on drugs, there are no official statistics available that show representative results $[42,43]$. The European School Survey Project on Alcohol and Other Drugs (ESPAD) studied alcohol, cigarette and drug use among 15 and 16-year-olds in 2011 and shows that Kosovar substance use was among the lowest in their study [44]. Especially alcohol use in Kosovo was much lower than in other European countries. The Kosovo Centre for Security Studies addressed the citizens' perceived security threat posed by drugs in the first (2012) [45] and fourth (2014) [46] edition of the Kosovo Security Barometer (KSB). Although over 80 percent of respondents indicated that they perceived drugs and alcohol as a high risk to societal security (the highest percentage of the listed internal risks, followed by 'thefts and murder' and 'illegal weapons') in the first edition of the KSB [45], the question was omitted in the following editions. Threats posed by drugs only came to the fore once more, in the fourth edition, when posing an open question to identify main threats according to Kosovo citizens. "Following the level of unemployment and general economic situation, the respondents have mentioned [...] other negative phenomena such as criminality, insecurity, thefts and drugs [as main internal threats to security] ([46], p. 15)." About 10 percent of respondents argued that "other negative phenomena', including drug-related threats, pose the main internal threats to security in Kosovo [46]. Moreover, the Labyrinth Centre, an NGO dealing with the prevention and treatment of drug and alcohol abuse in Kosovo since its founding in 2002, reported that there were only a handful of patients with drug abuse issues at the University Clinical Centre of Kosovo in April 2019, and just under twenty addicts were registered for continuous methadone treatment. The total number of registered drug users at the Labyrinth MedicalPsychotherapeutic Centre was 1262 between 2002 and 2019 [47]. Although these data are more recent, they are not representative, lack a large-scale perspective and cannot show trends or comparisons, all of which would render the data more prone to analysis. This shows the importance of recurrent representative studies on drug (ab)use in Kosovo [42,43,48].

Finally, statistics provided by the Kosovo Police at request show strong variations on both the amount of persons arrested and the amount of drugs confiscated in recent years. Marihuana is the most commonly confiscated drug, and there has been a strong increase in confiscated heroin in 2017, and especially in 2018 and 2019. While these data may give some insight into the amounts of narcotics flowing through Kosovo, they do not show if they were meant for do- 
mestic or foreign markets. Especially heroin is transported along the Balkan route towards markets in Northern and Western Europe [49,50].

Substance (ab)use came to the fore in five out of nine focus group discussions and is seen and treated as a serious insecurity for youth. This girl from Pristina stated "I know people who use drugs, but I also know people who say: 'I'm not stupid enough to use drugs!' So there is a 50-50. But it is still an issue as long as the other $50 \%$ is using it." Many respondents argue that a large responsibility for the prevention and repression of addictive substance (ab)use lies with parents as well as police.

Ironically, police efforts of preventing addictive substance (ab)use in school campaigns does not seem to be followed through when it comes to addressing actual addictive substance (ab)use and dealing, according to the participants. Police-school campaigns are one of the intervention methods gleaned from other (Western) contexts. If they are not followed up with adequate policing on drug dealing and (ab)use, well-meant school campaigns may have a counterproductive effect: placing police in a position of hypocrisy and giving off the feeling of ticking a box. Although illegal drug dealing is not visible to some, others have first-hand experiences with drug dealings taking place in their neighbourhood. Participants from Mitrovica, Ferizaj and Prizren describe 'publicly known' drug hotspots where no police intervention takes place. This girl from Mitrovica states: "I know a boy who sells drugs in front of kids, in front of people, in front of the police. I know. I have seen it with my own eyes!" Even when dealers are arrested, they tend to get back on the street "too soon", continuing with "the same things, the same way." Since Kosovo is part of the notorious Balkan route for drug smuggle into Western Europe, it is important to set up an effective network to stop large-scale drug smuggle and dealing at lower scales $[48,49,51]$.

Again, most young Kosovars cannot overcome these insecurities by themselves and rely on police for prevention talks and intervention. When asked if and why young Kosovars take part in drug dealing, a link to unemployment and the poor financial situation was immediately made: "[They don't] sell it for luxury, but they take risks to survive."

\subsubsection{School-related Insecurities}

The educational system holds a central role in the lives of many young Europeans, Kosovars included. Most youngsters spend large amounts of time on school or university grounds and school (or college/university)-related insecurities came to the fore quite often. Four main school-related insecurities were addressed: (1) violence and bullying in (and around) schools, (2) poor teaching, (3) nepotism and (4) a lack of study fields. The latter could be seen as one of the less pressing issues, referring to the limited variety of study fields offered at university colleges in Kosovo. Still, it is yet another reason for youth to leave the country and wanting to study abroad (see 5.1.1).
Considering the central role of schools (and universities) in young lives, it is of great importance that the youth' safety is ensured there. Nevertheless, many youth experienced violence in schools, either among students or in the form of force by school-personnel. Among students, both verbal and physical violence seems widespread. Many participants argue that bullying is a poignant issue at their respective schools, which also continues outside of school grounds. For some, according to respondents from Pristina, persistent victimisation by bullying can lead to feelings of depression or anxiety and even suicidal thoughts. These negative effects also show from literature on bullying [52]. Although some participants have engaged in so-called anti-bullying clubs and created movie messages to counter bullying in their schools, there is a lack of sustainable evidence-based anti-bullying programs in many middle- or low-income countries like Kosovo. "Evidence-based anti-bullying programs are only rarely implemented [...], mostly because their implementation requires extensive amounts of resources that are not readily available" ([53], p. 73).

Various participants state that they have witnessed armed fights (i.e. with knifes or even firearms) and some even noted cases in which a student died on school grounds after a fight. In Mitrovica, this girl experienced the following: "In my school there was a case, a student was attacked [...], the student was shot and killed and this happened right on the school entrance." Many students refer to the role of the police in such extreme fights and opinions vary on the police's ability to ensure safe schools. This girl from Pristina, for example, wonders whether the police work effectively enough: "I remember, after I graduated, there was a fight in high school and it got pretty bad because two kids had knives $n$ them and the police came and the fight was stopped [...]. Something like that would happen. And then, a year later, there was a shooting on high school grounds and a boy died. [...] That makes you think, how are the police working to keep us safe?" In regards, many schools and universities have engaged either police or private security guards for surveillance on school grounds. There were also cases noted in which a somewhat more pro-active resolution was employed: some students are searched (for weapons, drugs, and other unwanted goods) before entering school grounds.

The use of force by school-personnel surfaced less often during the focus group discussions, but is important to note, nonetheless. A girl from Pristina, for example, describes the following scene: "A school principal removed a girl's hijab forcefully in front of all of the students, you know, in order to do something like this you would have to be conscienceless" (see 5.1.6). However, students usually seem to refrain from reporting misconduct, according to this boy from Mitrovica: "Most students are hesitant in expressing their problems. I am in the position of chairman of parliament and still no student has reported a professor for misconduct even though I know there a lot of cases." There seems to be a need for more supervision of school-personnel in this regard. Moreover, teachers tend to dismiss students who for some 
reason are deemed troublesome in class. Kosovar students often land on the streets when dismissed from class, instead of staying on school grounds. Respondents argued that this could put them in dangerous situations, depending on the age and background of the student.

Another identified difficulty related to schools lies with its teaching. Some youth complained about the poor quality of teaching from old-fashioned teachers: "[The student] feels tired, because for seven hours [...], [the student] has a communist teacher who does not know anything. Who, for 30 years, has [had] the same notes [...] and says 'take the pen and write!'. [A teacher] who does not [include] anything interactive [...]." Some (formal) efforts have been made to shift the traditional educational culture in Kosovo to, for example, learner-centred education [54,55]. However, change is often resisted by educational leaders, and - as noted by respondents - teachers. "Transitioning from understanding to implementation should be supported vis-à-vis an educational culture that embraces this new philosophy as a precondition to successful change of teacher beliefs and practices" ([53], p. 60).

Furthermore, when it comes to teaching, the AlbanianSerbian tension in the North of Kosovo leads to gaps between the educational curricula. This Albanian-Kosovar boy from Mitrovica argued how some Serb students were taught misleading information in school: "During the contact I had with some Serbs, I noticed [...] that they are wrongly informed. Either it is information they have learned by mistake or they have been brainwashed by the media and their educational system. They think that, during the war, about 13 thousand Serbs were killed [56], which, in my opinion, is very untrue, because the majority who suffered loss and damage during the war were Albanians. [...]." The ethnical conflicts between Albanian and Serbian Kosovars has left its mark on the educational system. During the rising ethnical tensions in the 1990s, Kosovar Albanians established an underground parallel schooling-system as [54] "a reaction to the Serbian government's measures demanding that only the Serbian language and history be taught in public schools." Even today, a parallel system remains. This time, however, Serb communities reject the integration of their educational system into the mainstream Kosovar educational system. Although educational reform is one of the key priorities of the Kosovar government ("to promote [a] democratic and multi-ethnic society"), integrating the ethnically defined school-systems of both sides has not been treated as a high priority ([57], p. 91). This is of great concern, as (higher) education is seen as a crucial component of political transformation, contributing significantly to the peace and reconciliation process [56].

Finally, the widespread power relations surrounding nepotism are also found in the educational system: whether it is about getting into certain universities or about bargaining for better grades, family (or friends) in higher places are valuable social capital in the educational career too. In Prizren, "if you do not have family [or anyone familiar] inside, or know people, you can't be registered in university", a girl stated. A girl from Mitrovica also describes how connections seem more important than skill, as she addresses the prevalence of nepotism in high schools and universities as follows: "I have seen someone hand in a blank paper with no answers during the entrance exam and then they are first on the acceptance list. No one can convince me that that person deserved a place in the university, because I know in high school they barely graduated. In every institution it's obvious there is nepotism." It is no wonder that many argue that nepotism, like corruption, is everywhere in Kosovo.

\subsubsection{Physical Dangers}

Physical dangers belong to insecurities with which police and parallel security providers in Kosovo are most directly concerned with: and there are a lot. In general, it can be said that physical insecurities are strongly represented not just by being unsafe, but also by feeling unsafe. Five identified insecurities were linked to physical dangers, whether it be merely feeling unsafe or actually being unsafe: (1) dangerous traffic, (2) (violent) property crime, (3) attacks or abuse (e.g. due to ethnical conflicts), (4) homicide and (5) gender-based violence.

First of all, the dangerous traffic poses a risk to both young and old Kosovars, noted participants. There seems to be low law abidance when it comes to traffic rules and driving in the Balkans [58]: "Burim Krasniqi from the Ministry of Infrastructure believes that stricter law enforcement by police is overdue and can help to reduce the number of accidents." Police data from 2013 to 2019 show that there were between 110 and 129 road deaths annually [59]. This roughly amounts to seven road deaths per 100.000 residents. Although the amount of traffic tickets issued in 2019 increased as opposed to the previous year (+ 11.09), the amount of traffic accidents also rose $(+2.17 \%)$. Despite "great efforts to increase safety in road traffic" from the Kosovo Police, the amount of (fatal) accidents remains problematic. There are several international handbooks on road safety, but [60]: "local [road traffic] experts have to assess if and how results from these studies can be transferred to their own settings." In Kosovo, effective road engineering can be challenging due to limited resources and a lack of data and information for road improvement [61].

Secondly, (violent) property crime such as burglaries and robberies stem from the poor economic situation and tight job market in Kosovo, according to the participants. There is a strong presence of organised crime gangs, which may have a part in robberies too, however, gang activities were not discussed in any of our focus groups. Only a few participants identified such dangers as insecurities, and only a few actually experienced them. According to data from the United National Office on Drugs and Crime (UNODC), Kosovo ranks low compared to many other European countries when it comes to reported property crimes $[62,63]$. In 2018 , the rates per 100,000 inhabitants were 256.81 for burglaries, 324.37 for theft and 11.95 for car theft. The most recent available rate for robberies in Kosovo lies at 17.21 
in 2017. It must be noted, however, that these data rely on reported cases to police, which is not as common in Kosovo as it may be in other European countries.

The UNODC data on serious assault show a similarly low ranking for Kosovo in the European region (rate of 16.98 per 100,000 in 2018) [61,62]. Nevertheless, respondents emphasized the fear of attacks or abuse multiple times (which, of course, need not be serious assault cases or may not be reported to police (as such)). Some youth described that, at times, they even fear for their lives due to aggression of other individuals. The homicide rate in Kosovo was among the highest in the other former Yugoslavian states shortly after Kosovo declared its independence, but has gone down considerably in recent years [64]. Having witnessed violence and even killings on school campuses (see 5.1.4), it is not surprising that many young Kosovars carry this fear with them. The threats do not come from peers only, "I know many cases from my colleagues [including himself, ed.], who have asked questions to the prime minister and have been threatened with life", a boy from Pristina said. This poor environment for critical feedback shows how toxic the relationship between youth and their government is. Next to numerous fights taking place on school grounds (see 5.1.4), participants identified two groups who are argued to cause fights and at times attack others: mentally instable individuals in Ferizaj and Serbian troublemakers in Mitrovica. The first is addressed below and the latter is addressed in the next section (see 5.1.6).

In Shtime, a small village near Ferizaj, Kosovo's largest mental health facility is located. "The facility is [too] small and not able to house all the people who need help and so some of them end up on the streets. Some of them are violent and cause problems," youth stated. Back in 2002, a UN mission representative already "admitted that conditions at Kosovo's largest mental hospital, the 285-bed unit at Shtime, south of Pristina, were particularly bad" [65]. Youth have reported, "In our town square, there a lot of people with mental disabilities that walk around, and when I go past my school I get scared, I have to change my direction because it's not safe." International interventions for mental health were initiated to help address the psychological blows the recent Balkan conflicts took on their people, but have not been able to solve all deficits [66,67]. Although problems surrounding mental health in Kosovo are studied to some extent (for example, $[65,66,68]$ ), studies showing the problematics for those living near overcrowded mental health institutes are lacking.

Finally, youth describe certain physical dangers to be more prone to women than to men. Kosovar women and girls are victims of sexual abuse and domestic violence more often than males [69], as is the case in many countries. Kosovo ranks highest in the UNODC data for SouthEurope on reported sexual violence (24.7) and sexual exploitation (15.5) rates per 100,000 inhabitants, but these rates lie below those of many Northern and Western European countries $[61,62]$. It would be inaccurate, however, to conclude that sexual violence and exploitation is thus simply less apparent in Kosovo. Previous research has pointed out that many women do not report cases of sexual abuse to police. Stigmatization of victims of sexual abuse keeps them from reporting and also makes finding justice particularly difficult $[70,71]$. Respondents pointed out that even when cases are reported, they are not always taken seriously. According to this girl from Ferizaj: "The police are active and working only when it's very serious, when something very bad has happened. For example, when I have issues with the boys in my class, or even when I am harassed in the street, I report the incident and they do not do anything. Even though it bothers me very much. You cannot find a solution with the police, even though that is where you are supposed to find solutions."

Kosovo is taking formal steps towards addressing gender-based violence (e.g. the adoption of a reparations law for wartime sexual and gender-based violence [72], launching of integrated database on cases of gender-based violence and recognizing domestic violence as a standalone criminal offence [73]; all in 2018). However ([72], p. 28), beside the aforementioned, "there are concerns about lenient sentencing in cases of gender-based violence. Sustainable funding for shelters for victims of gender-based violence and trafficking in human beings has still not been ensured. Measures need to be taken for the effective reintegration of victims."

\subsubsection{Ethnical and Religious Tension}

The most prevalent and deeply rooted tensions in Kosovo remain based on ethnicity - intertwined with religion to some extent. Albanians and Serbs who once lived peacefully as neighbours turned to archenemies during and after the collapse of Yugoslavia. Nationalism sprung in the Balkans and, while leaping into a large-scale civil war, one after another separated from Yugoslavia. Kosovo, which had been part of Serbia, sought independence in 2008. Many Albanians see the Serbs as the main aggressors in the conflict, while Serbs blame Albanians for annexing land considered theirs. Therefore, there is an ever-present tension between the Albanian majority in Kosovo and the Serbian minority clustered mainly in the North. This has put especially young Kosovars in an identity crisis, be it in different ways.

"Apart from diverging nationalist aspirations, ethnic differences between the groups also coincide with language and religious differences ([74], p. 4)." Language and culture are at the core of Albanian ethnic identity forming, surpassing religious identity. Previous studies have suggest that religion is more important for Serbs, although religious identity may not serve the same way in today's society [73].

Results from our focus groups indicate that language may have gained emphasis in Serb identity forming and their identifying of out-groups in Kosovo. An Albanian-Kosovar respondent took "watch your language" to a whole new level, stating: "When we go there [North-Mitrovica with Serb majority], we barely speak Albanian, because if they hear you speaking...". Language is a way in which 'troublemakers' 
(be it Serb or Albanian) identify their in-group and potential targets from the out-group. Moreover, participants from Prizren spoke about conflicts between the Turkish (speaking) population and the Albanian speaking majority. This girl, however, seems to have found that socializing and communication is key in resolving these insecurities. "I have some friends that speak Turkish [...], most of the time we communicate in Turkish [...]. When I said a Turkish word, [others] were swearing 'why are you speaking Turkish?' [...]. But now, they are used to us, and are more curious to learn something new, and by socializing with them I think this problem can be resolved." Although Turks and Albanians do not share the same conflict as Albanians and Serbs do, this resolution does show promise. Under the right conditions, similar contact between peers may be beneficial to strengthening the relationship between Serbs and Albanians too (contact hypothesis [75]) $[73,76]$.

Although the majority of the Kosovar society is Muslim (95.6\% according to the Kosovo Census which was boycotted by many Serbs [77] 88\% according to the European Social Survey [78] religion is not generally seen as a core part of the Albanian identity [73]. This sometimes leads to situations like this: "One day a man was looking weirdly at me and was walking towards me, I think he wanted to remove my hijab but I quickly left." The same issue arose in schools where participants were not allowed to wear a headscarf until recently. Even though there is a Muslim majority in the Kosovar population, wearing affiliated clothing is sometimes frowned upon, as it does not fit the moderate religious environment. In Kosovo, religion is a private matter and bears much less importance than ethnicity (i.e. Albanian versus Serb) [73,79]. At the same time, however, religious radicalization has become a hot topic in Kosovo since many young Kosovars left for Syria [80]. Multiple recent studies explore the parallelism between relative secularity and radicalization in Kosovo (for example, [79,81,82]. Despite this, religious radicalization did not come the fore in our focus groups and is thus not explored here.

Albanian youth in Mitrovica are particularly concerned with Serb 'troublemakers' who mainly roam the Northern part of the city. A boy from Mitrovica argues that the Albanian-Serb tension sometimes lead to (feelings of) unsafety, "because we cannot move there [North-Mitrovica] freely. [...] Because there are [Serbian] gangsters and people brought there to make trouble." Youth also describe seemingly random attacks by Serbs when crossing the main bridge. In turn, Serb youth stated that they were bullied by their Albanian peers. For example, a Serbian girl stated, "Some Muslim kids back in the high school were bullying me because of my nationality. We were fighting often [...]."

Nevertheless, there is some sympathy from Albanian Kosovars for their Serb peers: "Not all the Serbs [are troublemakers], because they are also like us: they want to work, they want to have good conditions to live in," this boy from Mitrovica insists. Serb participants indeed noted concerns revolving unemployment, as well as multiple physical and school-related insecurities that are similar to those experienced by the Albanian population.

The Ibar River that divides the city into its infamous Northern (Serbian) and Southern (Albanian) sides symbolically underline the ethnical division in Mitrovica - and Kosovo. This division is even visible in the local police force (see 5.2.2).

In order to better the relationship between Serbs and Albanians in Kosovo, the political environment needs to become more inclusive. International resolution efforts had some formal success (e.g. "The First Agreement of Principles Governing the Normalization of Relations", established in 2013), but real reconciliation seems far away. "Every time conflicts are mentioned, we immediately go to the [relationship] between Serbs and Albanians. [...] The only thing that makes us feel unsafe [...] is the politics. Because earlier Albanians and Serbs got along very well, but now, politics have separated them. Politics are creating this unsafety," a respondent from Mitrovica argued. Political normalization is needed to re-establish harmonious relationships between Serbs and Albanians in Kosovo. Moreover, insecurities (e.g. described in this study) need to be addressed ([75], p. 100-101): "Reconciliation goes beyond conflict resolution and addresses the social and emotional barriers to improve ethnic relations. In this context, peace negotiations influence ethnic relations and consequently identity formation process. [...]. There is a lack of political will to build an identity that goes beyond ethno-national affiliation."

\subsection{Part II: Attitudes towards Police}

The international community (notably the OSCE, UN, EU and individual foreign states) has influenced and guided peace building and security sector reform in the Western Balkans shortly before, during and after the Yugoslavian conflicts. Over the years, the direction of these reforms have fluctuated, sometimes resulting in paradoxical approaches and goals - hampering effectivity [83].

During the intervention phase, creating a trustworthy and accountable police stood in focus, because "policing in socialist systems was oppressive and not citizen-oriented"; and, "police had lost its role as a defender of law and order and instead become a tool for conflict and war" ([82], p. 461462). Next to international monitoring and accountability mechanisms, the EU aimed to make police more responsive to citizens (i.e. shift from force to service), e.g. by making the composition of the police more representative. However ([82], p. 463), "in order to recruit minorities into the police they would need to return to the area. Yet, their return is hampered by the lack of confidence that the police would be able to guarantee their safety."

After Kosovo declared independence and a new police force was established, a division remained between Serb and Albanian officers (see Par I 5.1 .6 and Part II 5.2.2). The intervention reforms did not change attitudes of police officials nor the political culture. "Concerns about the real 'human security' situation for individuals on the ground, in particular vulnerable groups [...] remained" ([82], p. 464). 
Moreover, a main concern regarding international police reforms in the Western Balkans is the way in which foreign forces seem to impose reforms, lacking (sufficient) consideration of local experiences with police and other state-led security forces, as well as insufficient support of local elites [84]. Sustainable development in these areas must be supported by political commitment of domestic actors. In Kosovo in particular, there was a lack of security in the immediate aftermath of the NATO interception in 1999. This may not only have given way to criminal groups taking hold, but also ([83], p. 17) "shaped relations between Albanians and Serbs until today, created the enclave structure into which Serbs withdrew and undermined trust of Serbs and other minorities in the effective security provision and guarantees by NATO and other international organizations."

Whether or not the efforts for a trustworthy, accountable, ethnically diverse policing body show from youth' ATP, remains questionable. The ATP voiced by the participants are analysed and categorised alongside three perspectives: performance-based, the distributive justice and the procedural justice. The latter is divided into friendliness, neutrality, participation potential and trustworthiness.

\subsubsection{Performance-based perspective}

Topics surrounding police were discussed thoroughly in the focus groups. From a performance-based perspective, participants generally argue that police do not "do their job" nor provide a feeling of safety, as noted previously (see 5.1.5). Part of these negative opinions are formed by experiences of ineffective police interventions and prevention of fights among students at schools (see 5.1.4). Another performance-based perspective that affects ATP is related to their responses to emergency calls. In some cases, response speeds were satisfactory. The general tendency, however, is that police are "always late" or even unreachable by phone. For example, "On the town square, one was stabbing another with a knife. We all saw it and called the police, but they did not answer. [...]. We all saw it, women crying, children; nothing!" Multiple participants had experienced or heard of similar cases at which no one answered the emergency hotline.

Furthermore, police performance is negatively affected by miscommunications and misunderstandings in arrests: "We had a case with our neighbours. The police came to their house several times claiming someone had done something illegal but they had mistaken the person and there were always misunderstandings, this didn't happen once but a number of times, and they always convicted the wrong person. This is absurd!" The reason for these mix-ups remain unknown to the respondents.

Finally, in almost all focus group discussions, young Kosovars voiced the feeling that police are not capable or motivated to investigate cases and help citizens with their troubles. Some examples of lacking investigation and help from police were noted in previously. In short, "people always say 'hope no one will need them [ed. the police]' [...].
This makes you suspect that they will not help you if you need them. And often, we hear cases when citizens do not report problems at the police station, because they know that the police won't help and will only waste their time." Police's poor (motivation for) investigation thus keeps residents from engaging police for emergencies and reporting offenses. "My friend had a fight and when he wanted to report it to the police, a police officer said 'Do not report it, because it is not worth it. No one will take care of it.", a girl from Prizren explained.

Concluding, many factors cause youth to view police performance as poor. However, many see internal aspects of the Kosovar police as limiting and thus causing poor performance to some extent. On the one hand, youth argue that "maybe, they [ed. the police] did not want to risk their lives, but it is somewhat absurd. Perhaps this is a result of low salaries. Why risk your life for 200 or 300 euros?" These low salaries in combination with poor health insurance may not be the best motivation for police officers to intervene in potentially dangerous situations. Moreover, participants pointed out that police are often "old" and "old-fashioned", potentially limiting effective performance: "I think the police should be 'in' with the $21^{\text {st }}$ century. But somehow they are still in the last century. One case happened to a person I know, thieves entered his home and stole an iPad or something. Police came, pretended they were doing something, looking at the window. They did not know how to find the thief. This person had the "find my iPhone" app on the phone [...]. When he told the police about this they were like 'How did you do this?' They were surprised".

\subsubsection{Distributive justice perspective}

When inspecting the discussions on ATP with a distributive justice perspective, four characteristics were distilled: (1) police treat people with power differently, (2) youth calls are not taken seriously and (3) police do not go everywhere due to ethnical tensions. The power relations in Kosovo have surfaced multiple times in the focus group discussions as they do here: "For example, the traffic fines, if they see a simple person, they give them a fee, and if it is someone with power, authority, they cannot even stop them nor give them a fine.", a girl from Pristina says.

Moreover, emergency calls or reporting from young Kosovars are sometimes not taken seriously. This leads many to utilize different mechanisms for problem resolution (i.e. resorting to family members): "If we feel insecure we just call our family members. There is no hope for the police because if he [ed. the police officer] sees you: 'Oh it has to be your fault because you're young. You don't know all the rules' or something."

The ethnical tension and affiliated police division by ethnicity leads to unequal distribution of police forces in Mitrovica. Albanian police officers work in the South and Serbian police officers are employed in the North, backed by international forces such as the NATO-led peacekeeping Kosovo Force (KFOR). Youth voiced their concerns, arguing 
"KFOR isn't going to stay here forever, neither is the international police. Then we'll be left with these policemen who have never actually, maybe, been on the northern side. You have to know what you're doing." Local police forces stand before the challenge of being able to ensure the security of all residents of Mitrovica before the international police forces withdraw. Withdrawal issues are not just a problem for international police forces, but for many other internationally led initiatives and projects dependent on foreign donors as well. Also, research suggests that "the often intrusive approach of external actors in domestic security provision can certainly be seen as being benign in intent, but it can also undermine not just citizen trust in the state which is instead placed in external security providers. It also creates new power-relations which links citizens to external actors" ([83], p. 17-18).

Sometimes police - those who should provide (a feeling of) security - have a counterproductive effect on youth's perspectives of security. Increased police activity in Mitrovica can strengthen (feelings of) unsafety: "There is the bridge, and there is police all over. And sometimes when there is a fight or a protest, the police gets doubled and there is like these huge tanks protecting the, you know, "border", [...]. You don't feel safe when you see the people with machine guns in the patrol and the police. You cannot feel safe." Other participants describe that, due to a lack of trust in the police and a general mentality arguing that police are only there when "something bad has happened", police presence does not necessarily provide (a feeling of) security.

\subsubsection{Procedural justice perspective}

The procedural justice perspective regarding police forces in Kosovo is analysed alongside four sub-sections. First of all, although some youth noted polite and understanding behaviour of police, others addressed harsh and arrogant behaviour by police. In part, youth argued that police sometimes use harsh behaviour and force to "scare" others and keep them from making the same mistakes. To some extent, this hinders the development of a healthy relationship between police and communities and gives way to fear: "In most cases we are a little afraid, because when you get closer they have angry look, and a voice sound like they are going to shout at us, for something not important."

The limited neutrality of police is strongly affected by the power relations at place. In general, Kosovar youth views police as corrupt and subject to nepotism: "In Kosovo, you just tell them whose son or daughter you are, or that you know someone [...], and then easily you can corrupt them [ed. the police] with money too." A girl from Mitrovica experienced this firsthand when she got stopped for a speeding and was allowed to drive off without a ticket because the police officer recognized her last name and appeared to know her grandfather. Once again, these statements indicate how widespread corruption and nepotism are in Kosovo.

Regarding participation potential, the general tendency is - again - poor. Although school campaigns and patrols increase the approachability of police officers according to the participants, the relationship between youth and police is generally described as poor. The fact that many Kosovars do not know the emergency number underlines this distant relationship. This girl from Pristina states, "I think the relationship between the police and the people is basically non-existent here. A couple of months back, [...] journalists would go on the streets and they were asking people: 'What's the police number here in Kosovo?' [...]. And more than half didn't even know the number. [...]. That's how much we use the number; so that we don't even know the number." The emergency number in Kosovo has changed over the years and seems to have caused confusion: it was 092 during the Yugoslavian regime, 112 after the Kosovo war ended and 192 since the declaration of independence in 2008. All in all, there are steps to be taken in order to improve response calls. There is a wish among the respondents for more communication and cooperation with youth and more transparent information sharing from the police to improve the participation potential.

Finally, only one participant (from Mitrovica) voiced that he trusts both the international and local police. All others deemed the police, like many other Kosovar institutions, untrustworthy in general. Many participants stated that they trust international police forces such as KFOR more than local police, because the assume them to be less "influenced" by, for example, corruption. Also "KFOR [...] are considered higher rank than the [local] police and I think they helped reduce some problems that were apparent here," according to our participants. The friendliness of KFOR officers also improved trust in KFOR among some of our participants. All other statements regarding trust in both local and international police were performance-based as previously described (see 5.2.1). In short, this means, "if I heard more cases that the police succeeded and they'd done their job then l'd be more trustful. But that's not the case."

\section{Conclusion and Discussion}

This study aimed to give Kosovar youth a voice and put the human in human security. "As reflexive beings capable of computing complex security dilemmas and active agents in the construction of safer environments, individuals can thus reclaim their rightful place in a person-centred concept of security" ([16], p. 582). In Part I, insecurities and resolution mechanisms (i.e. agency) of young Kosovars were analysed. Part II addressed perceptions and importance on performance, the procedural justice and the distributive justice of police in Kosovo. Primary data from semi-structured focus group discussions with Kosovar youth were used to explore a large scope of insecurities when growing up in post-conflict Kosovo.

Four main insecurities were identified in Part I: (1) job-related (including job-related discrimination), (2) drugrelated, (3) school-related, (4) physical insecurities. Both Serb and Albanian focus groups identified similar insecu- 
rities in their everyday-lives. Ethnic and religious tensions were a recurrent crosscutting theme, related to most of the aforementioned insecurities. However, many of the identified insecurities are also interconnected and seem to spring from the weak economic status of Kosovo. Also, both actual and perceived insecurity are relevant to human security of individuals. This became especially clear when addressing physical dangers: many feared physical dangers, but only a few experienced them. This can be caused by an exaggerated perception of crime rates or by successful avoidance mechanisms - or both. One respondent concluded: "I would say that there are other insecurities [...] and these [...] may be much more difficult than physical ones."

Any peace-making efforts should therefore take the social and economic context in Kosovo into account when addressing human security. Furthermore, there seems to be a discrepancy between the many action plans and handbooks (formal change) on the one hand, and effective implementation on the other (actual change). Benchmarks of international missions (such as EULEX) are often exclusively quantitative, although many aspects of peace and security cannot be measured that way. "It is important to assess missions not as box-ticking exercises, but rather carefully consider the extent to which effectiveness criteria are met" ([85], p. 600).

Moreover, this study suggests that language has gained importance in establishing out-groups and (thus) identity, especially for Kosovar-Serbs whose identity has previously been argued to find its core in religion, rather than language [73]. A similar language division was observed between Albanian (for whom language and culture are core) and Turkish youth. Here, frequent contact in and around school helped to improve relations between both groups, conform to Allport's contact hypothesis [74]. Future research could explore if and under what circumstances this may apply to the relation between young Albanians and Serbs.

Similar to the findings of Kostovicova et al. [16], youth may employ small-scale resolutions, but are unable to change the large-scale problems in Kosovo. Here too, a paradox exists between the insecurities experienced by youth and their agency to change it. For example, youth named nepotism and corruption as something that causes insecurity to them. To cope with the consequences this has for, for example, finding a job, they too (have to) use corruption and nepotism to their advantage. This develops a vicious circle. Young Kosovars were often unable to resolve insecurities directly and individually. Most problem resolution revolved around avoidance and withdrawal on the one hand (i.e. self-reliance), and initiatives from peers and family (i.e. informality \& community solidarity) on the other. To many, the ultimate resolution mechanism is emigration into EU states for work and/or studying, which showed from the mass emigration movement, which took place in 2015. Many feel like "there is nothing here".

Both local and international police in the region are supposed to ensure the security of Kosovar youth and all other residents. Some of the identified insecurities, like unemployment, are difficult and/or not suiting for police to address. However, as addressed in Part II of this study, there is still much to be done if police aim to really be (seen as) a helping hand when it comes the resolution of insecurities in which the police do play a role (e.g. physical dangers). Most arguments for youth' ATP seem to spring from the performance-based perspective and procedural justice perspective as described in the theoretical framework, respectively. It indicates that youth find those two aspects of police most important; however, both aspects are generally evaluated to be poor. When it comes to trustworthiness of police - part of the procedural justice perspective - youth merely named performance-based arguments for their general distrust. Thus, to improve the ATP in general, as well as trustworthiness in particular, police need to perform better when it comes to tackling the multitude of insecurities young Kosovars experience when growing up in post-conflict Kosovo. With strong power relations still intact, this will prove to be a challenge for all. Besides, the future withdrawal of international resources and forces (such as KFOR) pose a challenge of their own.

This study looked at the individual stories of Kosovar youth, which had to rely on snowball sampling in order to reach out to respondents. Further randomized quantitative research is needed to be able see to what extent these insecurities and perspectives are felt on a larger scale. Difficulties lie with forming a representative sample, since many Serbian-Kosovars tend to boycott surveys and studies in Kosovo. For this reason, however, it may be even more interesting to look at the perspectives of Serbian-Kosovar in a more in-depth study. Future research can also investigate (hiring) discrimination on the basis of political preference and problems connected to overloaded mental health centres in, for example, communities surrounding Shtime. Moreover, there is a dire need for a long-term, representative study on drug (ab)use in Kosovo.

\section{Acknowledgments}

This article was written as part of the CommunityBased Policing and Post-Conflict Police Reform Project (ICT4COP), which has received funding from the European Union's Horizon 2020 research and innovation programme, under grant agreement No. 653909. The ICT4COP project focusses on (the improvement of) community-oriented policing in post-conflict zones. In order to successfully employ community-oriented policing strategies, a close relationship between the community and police is crucial. This article thus aims to help police and related actors in the region gain knowledge about the needs of the Kosovar youth community and their views of police in the region. I want to thank Coco de Jongh and Dr Kari Osland for their critical eye in proofreading this article before first submittance. 


\section{References and Notes}

[1] Kosovo Profile. Available from: https://www.bbc.com/news/worldeurope-18328859.

[2] Duijzings G. Religion and the Politics of Identity in Kosovo. New York, NY, USA: Columbia University Press; 2000.

[3] Hofmann R. Local Ownership and Community Oriented Policing: The Case of Kosovo. European Law Journal. 2018;doi:10.2825/908140.

[4] Anten L, Briscoe I, Mezzera M. Political Economy of State-building in Situations of Fragility and Conflict: from Analysis to Strategy. Clingendael Institute; 2012. Available from: https://issat.dcaf.ch/download/ 37996/562389/cru_political_economy.pdf.

[5] Kosovo and the EU. European External Action Service \& European Commission;. Available from: https://eeas.europa.eu/delegations/ kosovo en $/ 1387 /$ Kosovo*\%20and\%20the\%20EU.

[6] Janssens J. State-building in Kosovo. A Plural Policing Perspective. Maklu; 2015. Available from: https://books.google.com.mx/books? id=YS15BgAAQBAJ.

[7] Feltes T. Peacebuilding and Police Reform in the New Europe: Lessons from Kosovo. vol. 10. Sociedad Mexicana de Criminología capítulo Nuevo León; 2008. Available from: https://dialnet.unirioja. es/descarga/articulo/5259749.pdf.

[8] Corruption Perceptions Index 2018. Transparency International;. Available from: https://www.transparency.org/cpi2018.

[9] Kosovo: Data. World Bank;. Available from: https://data.worldbank. org/country/kosovo.

[10] World Report 2019: Rights Trends in Serbia/Kosovo. New York, USA: Human Rights Watch; 2020. Available from: https://www.hrw.org/ world-report/2019/country-chapters/serbia/kosovo.

[11] Kosovo Age Structure. Index Mundi;. Available from: https://www. indexmundi.com/kosovo/age_structure.html.

[12] Dirikx A, Gelders D, Parmentier S. Police-Youth Relationships: A Qualitative Analysis of Flemish Adolescents' Attitudes toward the Police. European Journal of Criminology. 2012;9(2):191-205. doi:10.1177/1477370811427518.

[13] Holliday I, Howe B. Human Security: A Global Responsibility to Protect and Provide. Korean Journal of Defense Analysis. 2011;23(1):7392.

[14] Human Security Now. New York, USA: Commission on Human Security; 2003. Available from: https://reliefweb.int/sites/reliefweb. int/files/resources/91BAEEDBA50C6907C1256D19006A9353-chssecurity-may03.pdf.

[15] Gregoratti C. Human Security. Available from: https://www.britannica. com/topic/human-security.

[16] Kostovicova D, Martin M, Bojicic-Dzelilovic V. The Missing Link in Human Security Research: Dialogue and Insecurity in Kosovo. Security Dialogue. 2012;43(6):569-585. doi:10.1177/0967010612463489.

[17] Eschholz S, Blackwell BS, Gertz M, Chiricos T. Race and Attitudes toward the Police: Assessing the Effects of Watching "reality" Police Programs. Journal of Criminal Justice. 2002;30(4):327-341. doi:10.1016/S0047-2352(02)00133-2.

[18] Tankebe J. Public Confidence in the Police: Testing the Effects of Public Experiences of Police Corruption in Ghana. The British Journal of Criminology. 2010;50(2):296-319. doi:10.1093/BJC/AZQ001.

[19] Wu Y, Sun IY. Citizen Trust in Police: The Case of China. Police Quarterly. 2009;12(2):170-191. doi:10.1177/1098611108330228.

[20] Tyler TR. Social Justice: Outcome and Procedure. International Journal of Psychology. 2000;35(2):117-125.

[21] Sunshine J, Tyler TR. The Role of Procedural Justice and Legitimacy in Shaping Public Support for Policing. Law \& Society Review. 2003;37(3):513-548. doi:10.1111/1540-5893.3703002.

[22] As the name suggests, two moderators are present in a dualmoderator focus group. For this study, the (native-speaker) interviewer was the main guide and made sure that all topics were covered, while I personally ensured a smooth progression of the session.

[23] Sampling management and revenue organisation in cooperation with the Iliria University in Pristina.

[24] All respondents gave oral consent for their participation, both when agreeing to participate (some time prior to the interview) and at the beginning of each focus group. They were informed on the purpose of the study and that everything stated during the focus group discussions is confidential. Names and input were anonymised. The following guidelines were laid out: (1) no one is obligated to answer to any question, (2) do not interrupt others and (3) there are no wrong answers or questions - every contribution is valuable. Stressing these guidelines are of increased importance when interviewing youth in particular.

[25] Nezaj NX. Kosovo's Transformation into a Market Economy. Hamburg, Germany: Ideas. Discussion Paper; 2015. Available from: https://www.econstor.eu/bitstream/10419/110955/1/827020422.pdf.

[26] Kosovo's Economy. Available from: https://www.mei-ks.net/en/ kosovo/kosovo146s-economy.

[27] Labor Force Survey in Kosovo: 2019. Kosovo Agency of Statistics;. Available from: https://ask.rks-gov.net/en/kosovo-agency-ofstatistics/add-news/labor-force-survey-in-kosovo-2019.

[28] Labor Force Survey, Q1 2020. Kosovo Agency of Statistics;. Available from: https://ask.rks-gov.net/en/kosovo-agency-of-statistics/ add-news/labor-force-survey-q1-2020.

[29] Unemployment, total (\% of total labor force) (national estimate) - Kosovo, Bosnia and Herzegovina, Serbia, European Union. World Bank;. Available from: https://data.worldbank.org/ indicator/SL.UEM.TOTL.NE.ZS?end=2019\&locations=XK-BA-RSEU\&start $=1990$ \&view $=$ chart.

[30] Unemployment, total (\% of total labor force) (national estimate) Kosovo, Serbia, Montenegro, Albania, North Macedonia, Bosnia and Herzegovina, Croatia, Slovenia, Greece, Hungary, Bulgaria, Romania, Europe \& Central Asia, European Union. World Bank; Available from: https://data.worldbank.org/indicator/SL.UEM.TOTL. NE.ZS?end=2019\&locations=XK-RS-ME-AL-MK-BA-HR-SI-GRHU-BG-RO-Z7-EU\&start=1980\&view=chart.

[31] Labor Force Survey in Kosovo: 2018. Kosovo Agency of Statistics;. Available from: https://ask.rks-gov.net/en/kosovo-agency-ofstatistics/add-news/labour-force-survey-in-kosovo-2018.

[32] Unemployment, Youth Total (\% of total labor force ages 15-24) (modeled ILO estimate). World Bank; Available from: https://data.worldbank.org/indicator/SL.UEM.1524.ZS?end= 2019\&most_recent_value_desc=true\&start=2019\&view=map.

[33] Kosovo's Economy Still Struggling Five Years After Independence. Available from: https://www.rferl.org/a/kosovo-economy-struggling/ 24901946.html.

[34] Hasanaj P, Ahmetaj B, Tërstena A. Employment Challenges of the Youth in Kosovo. Acta Universitatis Danubius CEconomica. 2020;16(3).

[35] Hempel K. Making Employment Services and Active Measures Sensitive to the Needs of Young People: Recommendations for Youth Employment Programs in Kosovo. World Bank; 2020. Available from: http://hdl.handle.net/10986/34135.

[36] In October 2016, the Kosovar government has reclaimed the Trepca mines in attempt to save it from bankruptcy, despite protests from Serbia. "Trepca straddles Kosovo's Serb-Albanian ethnic divide and, since the territory broke away from Serbia in 1999, the mine has been held in trust and readied for sale by an agency created by the United Nations. However, the Privatisation Agency of Kosovo (KPA) has failed to come up with a plan for the mine's future, partly due to its murky ownership structure" (Bytyci F. Kosovo Government Takes Control of Trepca Mine: Serbs Protest. Reuters. 2016).

[37] GDP per capita (current US\$) - Kosovo, Bosnia and Herzegovina, Serbia. World Bank;. Available from: https://data.worldbank.org/ indicator/NY.GDP.PCAP.CD?locations=XK-BA-RS\&view=chart.

[38] Milovanović D, Maksimović N. Could Social Enterprises Become (Another) Active Measure for Employment of Marginalized Groups in Kosovo. Social Enterprise Developments in the Balkans. 2018;99.

[39] Hajredini H, llieva M, Jashari H, Luzio N, Matijević M, Wnendt W, et al. Implementing the Anti-Discrimination Law: A challenge for Kosovo. Kosovo, RKS: Organization for Security and Co-operation in Europe; 2007. Available from: https://www.osce.org/files/f/documents/b/8/ 25854.pdf.

[40] Report Implementation of Anti-Discrimination Law. Law No. 2204/32. Youth Initiative for Human Rights; 2007.

[41] Arapi D, Vardari L, Gashi R. A Women in The Labour Market and Decision Making in Kosovo. Prizren Social Science Journal. 2017;1(1):1529. doi:10.2139/ssrn.3113760.

[42] Ismajli R. Perspectives on Drug Abuse in Kosovo. National Institute on Drug Abuse; 2008. Available from: https://www.drugabuse.gov/ 
international/abstracts/perspectives-drug-abuse-in-kosovo.

[43] Kosovo Country Overview: Prevalence of Drug Use. European Monitoring Centre for Drugs and Drug Addiction; 2013.

[44] Hibell B, Guttormsson U. A Supplement to the 2011 ESPAD Report: Additional Data from Bosnia and Herzegovina (Federation of Bosnia and Herzegovina), Kosovo (under UNSCR 1244) and the Netherlands. Stockholm, SE: The Swedish Council for Information on Alcohol and Other Drugs; 2013. Available from: http://www.espad.org/sites/espad.org/files/FULL-REPORTSupplement-to-The-2011-ESPAD-Report-WEB.pdf.

[45] Muja A, Perteshi S, Raifi F, Kryeziu S. Kosovo Security Barometer: First Edition. Kosovo, Republic of Kosovo: Kosovo Centre of Security Studies; 2012. Available from: http://www.qkss.org/repository/docs/ Kosovo Security Barometer Report English 152996.pdf.

[46] Vrajolli M, Emni D, Perteshi $\bar{S}$, Kryeziu S, Naka T, Desai T. Kosovo Security Barometer: Fourth Edition. Kosovo,RKS: Kosovo Centre of Security Studies; 2014. Available from: http://www.qkss.org/en/ Reports/Kosovo-Security-Barometer-Fourth-Edition-306.

[47] Kika R. Rast Studimor për Përmirësimin e të Drejtave të Njeriut të Përdoruesve të Drogave në Kosovë. Kosovo,RKS: Qendra MedikoPsikoterapike Labyrinth; 2019.

[48] Policy Implementation Against Illicit Narcotics. Forum for Civic Initiatives; 2011.

[49] Drug Money: The Illicit Proceeds of Opiates Trafficked on the Balkan Route. Vienna, AT: United Nations Office on Drugs and Crime; 2015. Available from: https://www.unodc.org/unodc/en/frontpage/ 2015/November/drug-money-and-opiate-trafficking-on-the-balkanroute--focus-of-new-unodc-report.html.

[50] Hotspots of Organized Crime in the Western Balkans: Local Vulnerabilities in a Regional Context. Global Initiative Against Transnational Organized Crime; 2019. Available from: https://globalinitiative.net/ analysis/oc-western-balkans/.

[51] National Strategy of Republic of Kosovo Against Narcotics and Action Plan. Kosovo, RKS: Republic of Kosovo; 2012. Available from: https://kryeministri-ks.net/wp-content/uploads/docs/ NATIONAL_STRATEGY_AND_ACTION_PLAN.pdf.

[52] PISA 2015 Results (Volume III). Organisation for Economic Cooperation and Development; 2017. doi:10.1787/9789264273856-en.

[53] Arënliu A, Strohmeier D, Konjufca J, Yanagida T, Burger C. Empowering the Peer Group to Prevent School Bullying in Kosovo: Effectiveness of a Short and Ultra-short Version of the ViSC Social Competence Program. International Journal of Bullying Prevention. 2020;2(1):65-78. doi:10.1007/s42380-019-00052-4.

[54] Zabeli N, Anderson J, Saqipi B. Towards the Development and Implementation of Learner-centered Education in Kosovo. Journal of Social Studies Education Research. 2018;9(4):4964. Available from: https://jsser.org/index.php/jsser/article/view/354. doi:10.17499/jsser.19588

[55] Siemens HM. What did we learn? International Fieldwork in Education [PhD Thesis]. University of Calgary. Calgary, Alberta, Canada; 2011.

[56] Supposing that the respondent is talking about the Kosovo war only, this seems to be overestimated. About 13,500 civilians, soldiers and police were killed during the Kosovo war between 1998 and 2000. Among those were 8,661 Albanians (84\%) and 1,197 (11.6\%) Serbs, according to an evaluation of the database of the Kosovo memory book (Krüger J, Ball P. Evaluation of the Database of the Kosovo Memory Book. Human Rights Data Analysis Group. 2014.).

[57] Baliqi B. Higher Education in Divided Societies: Between Ethnic Segregation and Citizenship Integration in Kosovo. Journal of Higher Education and Science;9(1):90-96. doi:10.5961/jhes.2019.312.

[58] E F. Dying on the Road: Demand for Action as Fatal Accidents Spike. Available from: https://kosovotwopointzero.com/en/dying-onthe-roads/.

[59] Hiseni I, Shefqeti S, Maliqi R. Annual Report 2019. Kosovo, Republic of Kosovo: Kosovo Police \& Republic of Kosovo; 2019. Available from: https://www.kosovopolice.com/wp-content/uploads/2020/02/ Raporti-vjetor-2019-anglisht.pdf.

[60] Wegman F. The Future of Road Safety: A Worldwide Perspective. IATSS research. 2017;40(2):66-71. doi:10.1016/j.iatssr.2016.05.003.

[61] Gashi E, Tille M, Mustafa G. Road Safety Audit from Design Point of View at the Western Balkan Countries. Journal of Engineering.
2016:4(2):193-203. doi:10.15640/jea.v4n2a16.

[62] Data United Nations Office on Drugs and Crime. United Nations Office on Drugs and Crime;. Available from: https://dataunodc.un.org/.

[63] "Differences [...] still exist between the legal definitions of offences in countries, the different methods of offence counting and recording and differences in reporting rates." [62].

[64] Intentional homicides (per 100,000 people) - Kosovo, Bosnia and Herzegovina, Serbia, Montenegro, Slovenia Croatia, North Macedonia. World Bank;. Available from: https://data.worldbank.org/indicator/VC.IHR.PSRC.P5?end= 2018\&locations=XK-BA-RS-ME-SI-HR-MK\&start=2008.

[65] Jennings C. Kosovo Mental Care Abuses Revealed. The Telegraph. 2002; Available from: https://www.telegraph.co.uk/news/1404014/ Kosovo-mental-care-abuses-revealed.html.

[66] Kienzler H. Mental Health System Reform in Contexts of Humanitarian Emergencies: Toward a Theory of "Practice-Based Evidence". Culture, Medicine, and Psychiatry. 2019;43(4):636-662. doi:10.1007/s11013-019-09641-w

[67] Kienzler H. "Making Patients" in Postwar and Resource-scarce Settings. Diagnosing and Treating Mental Illness in Postwar Kosovo. Medical Anthropology Quarterly. 2020;34(1):5976. Available from: https://www.semanticscholar.org/paper/ \%22Making-Patients\%22-in-Postwar-and-Resource-scarcein-Kienzler/9f9779ac6599de21cd0c81b7d7d7f6536f63d75d. doi:doi/10.1111/maq.12554

[68] Hyseni Duraku Z, Kelmendi K, Jemini-Gashi L. Associations of Psychological Distress, Sleep, and Self-esteem among Kosovar Adolescents. International Journal of Adolescence and Youth. 2018;23(4):511-519. doi:10.1080/02673843.2018.1450272.

[69] Maçastena A. Gender-based Violence in Kosovo. Acta U Danubius Jur. 2019;pp. 118. Available from: http://journals.univ-danubius.ro/ index.php/juridica/article/view/5488.

[70] Krasniqi V, Sokolić I, Kostovicova D. Skirts as Flags: Transitional Justice, Gender and Everyday Nationalism in Kosovo. Nations and nationalism. 2020;26(2):461. doi:10.1111/nana.12593.

[71] Wounds That Burn our Souls: Compensation for Kosovo's Wartime Rape Survivors, But Still No Justice. Amnesty International; 2017. Available from: https://www.amnesty.org/download/ Documents/EUR7075582017ENGLISH.PDF.

[72] Law No. 04/L-172 on amending and supplementing the law no. 04/L054 on the states and the rights of the martyrs, invalids, veterans, members of the Kosovo Liberation Army, sexual violence victims of the war, civilian victims and their families. Kosovo, Republic of Kosovo: Republic of Kosovo Assembly; 2014. Available from: https://reparations.qub.ac.uk/assets/uploads/04-L-172-a.pdf.

[73] Kosovo 2019 Report: Commission Staff Working Document. Brussels, Belgium: European Comission; 2019. Available from: https://ec.europa.eu/neighbourhood-enlargement/sites/near/ files/20190529-kosovo-report.pdf.

[74] Maloku E, Kelmendi K, Vladisavljević M. Who Is This New We? Similarities and Differences of Ethnic, Religious, and National Identity among the Albanian Majority and the Serb Minority in Post-Conflict Kosovo. In: Shaping Social Identities After Violent Conflict. Springer; 2017. pp. 113-133. doi:10.1007/978-3-319-62021-3.

[75] Allport GW, Clark K, Pettigrew T. The Nature of Prejudice. Addisonwesley Reading; 1954.

[76] Baliqi B. Politics of Identity and Ethnic Relations in Kosovo. SSRN Electronic Journal. 2014;doi:10.2139/ssrn.2734338.

[77] Quality Report Final Results: Kosovo Population and Housing Cencus 2011. CIRPS-Sapienza University of Rome, ICONINSTITUT and Rrota: Kosovo Agency of Statistics; 2011. Available from: http://unstats.un.org/unsd/censuskb20/Attachment488.aspx? AttachmentType $=1$.

[78] Dataset Comparison: Kosovo in Period 2006-2015. Swiss Metadatabase for Religious Affiliation in Europe; 2019. Available from: https://www.smre-data.ch/en/data_exploring/region_cockpit\#/mode/ dataset comparison/region/-99/period/2010/presentation/bar

[79] Totten $\bar{M}$. The (Really) Moderate Muslims of Kosovo. Available from: https://www.city-journal.org/html/really-moderate-muslimskosovo-13128.html.

[80] Knudsen RA. Radicalization and Foreign Fighters in the Kosovo Context: An Analysis of International Media Coverage 
of the Phenomena. NUPI Working Paper. 2017; Available from: https://www.rcc.int/swp/download/docs/NUPI_Working_Paper_ 875 Knudsen.pdf/b1e0d3c8333abdf8dd9e8f8cbce46b77.pdf.

[81] Zaimi G. Selected papers Terrorism Experts Conference (TEC) 2016; 2017. pp. 80. Available from: https://www.tmmm.tsk.tr/ courseconfpapers.html.

[82] Kursani S. Salafi Pluralism in National Contexts: The Secular State, Nation and Militant Islamism in Kosovo, Albania, and Macedonia. Southeast European and Black Sea Studies. 2018;18(2):301-317. doi:10.1080/14683857.2018.1474548.

[83] Flessenkemper T. European Union Approaches to Police and Human
Rights in the Western Balkans. The International Journal of Human Rights. 2019;23(4):454-475. doi:10.1080/13642987.2018.1503896.

[84] Bieber $F$, et al. Policing the Peace after Yugoslavia: Police Reform between External Imposition and Domestic Reform. GRIPS Policy Research Center; 2010. Available from: https://grips.repo.nii.ac.jp/?action=repository_action_common_ download\&item id=1028\&item no $=1$ \&attribute id $=20$ \&file no $=1$.

[85] Zupančič R, Pejič N, Grilj B, Peen Rodt A. The European Union Rule of Law Mission in Kosovo: An Effective Conflict Prevention and Peace-building Mission? Journal of Balkan and Near Eastern Studies. 2018;20(6):599-617. doi:10.1080/19448953.2017.1407539. 